\title{
Floristic and structural relationships in seasonally dry tropical forests on limestone outcrops
}

\author{
Relações florísticas e estruturais em florestas tropicais sazonalmente secas \\ sobre afloramento de calcário
}

\author{
Nathalle Cristine Alencar Fagundes ${ }^{1}$ (D), Aurélio de Jesus Rodrigues Pais ${ }^{2,3}$ (D), \\ Cléber Rodrigo de Souza ${ }^{3}$ (D), Paola Ferreira Santos ${ }^{1}$ (D), Hisaias de Souza Almeida ${ }^{4}$, \\ Fábio de Almeida Vieira ${ }^{5}$ (D), Ary Teixeira de Oliveira-Filho ${ }^{6}$ (D) Eduardo van den Berg ${ }^{1}$ (D), \\ Dulcinéia Carvalho ${ }^{3}$ (1), Rubens Manoel dos Santos ${ }^{3}$ (1) \\ ${ }^{1}$ Departamento de Biologia, Universidade Federal de Lavras - UFLA, Lavras, MG, Brasil \\ ${ }^{2}$ Departamento de Engenharia Ambiental, Universidade Zambeze - UniZambeze, Chimoio, Manica, Moçambique \\ ${ }^{3}$ Departamento de Ciências Florestais, Universidade Federal de Lavras - UFLA, Lavras, MG, Brasil \\ ${ }^{4}$ Instituto de Recursos Naturais, Universidade Federal de Itajubá - UNIFEl, Itajubá, MG, Brasil \\ ${ }^{5}$ Unidade Acadêmica Especializada em Ciências Agrárias, Universidade Federal do Rio Grande do Norte - UFRN, Macaíba, RN, \\ Brasil \\ ${ }^{6}$ Departamento de Botânica, Universidade Federal de Minas Gerais - UFMG, Belo Horizonte, MG, Brasil
}

\begin{abstract}
How to cite: Fagundes, N. C. A., Pais, A. J. R., Souza, C. R., Santos, P. F., Almeida, H. S., Vieira, F. A., Oliveira-Filho, A. T., van den Berg, E., Carvalho, D., \& Santos, R. M. (2020). Floristic and structural relationships in seasonally dry tropical forests on limestone outcrops. Scientia Forestalis, 48(127), e3294.

https://doi.org/10.18671/scifor.v48n127.17
\end{abstract}

\begin{abstract}
This study tested floristic and structural links existing in seasonally dry tropical forests (SDTFs) fragments on carbonate rocky outcrops among three (3) phytogeographic domains (Atlantic, Caatinga and Cerrado) in Brazil. Although included in large-scale SDTFs studies, these disjunctions under limestone are in part poorly understood and little is known about the diversity patterns in these areas. Thus, eight (8) fragments were sampled, three (3) from cerrado, two (2) from Atlantic and three (3) from Caatinga for phytosociological surveys and subsequent characterization of the structure and floristic composition. The structure differed from each other among fragments (even on the same substrate) and between the domains. There were greater similarities only between patches and its surrounding vegetation. However, key SDTFS species were shared among domains with high Coverage Value (CV). Climatic variables were essential in fragments differentiation by seasonality, separating Cerrado and Caatinga domains (higher precipitation seasonality and higher temperatures) against Atlantic domain by milder climate and higher altitudes. Thus, sampled patches presented metacommunity characteristics, with great floristic and structural dissimilarity conditioned mainly by climatic factors and by the influence of adjacent phytogeographic vegetation domains.
\end{abstract}

Keywords: Structure; Floristic; Deciduous forests; Phytogeographic Domains; Metacommunities.

\section{Resumo}

Este trabalho testou a existência de elos florísticos e estruturais em fragmentos de florestas tropicais sazonalmente secas (FTSS) sobre afloramentos de rocha carbonática em três domínios fitogeográficos no Brasil. Apesar de incluídas em estudos de FTSS em ampla escala, estas disjunções em solo calcário são pouco compreendidas isoladamente sendo que pouco se sabe sobre os padrões de diversidade nessas áreas. Deste modo, foram amostrados oito (8) fragmentos, sendo três (3) do cerrado, dois (2) do Atlântico e três (3) da Caatinga para o levantamento fitossociológico e posterior caracterização da estrutura e composição florística. A estrutura não apresentou semelhança, uma vez que os fragmentos

Financial support: Coordenação de Aperfeiçoamento de Pessoal de Nível Superior (CAPES); Fundação de Amparo à Pesquisa do Estado de Minas Gerais (FAPEMIG).

Conflict of interest: Nothing to declare.

Corresponding author: ninopais@gmail.com

Received: 20 February 2019.

Accepted: 24 September 2019

Editor: Paulo Henrique Müller Silva.

(c) (i) This is an Open Access article distributed under the terms of the Creative Commons Attribution License, which permits unrestricted use,

c) distribution, and reproduction in any medium, provided the original work is properly cited. 
diferiram entre si (mesmo estando sobre mesmo substrato) e entre os domínios, sendo encontrada maior semelhança apenas entre o fragmento e seu entorno. No entanto, espécies características e persistentes de FTSS foram compartilhadas, e obtiveram alto valor de cobertura (VC). As variáveis climáticas foram preponderantes na separação dos fragmentos, com a estacionalidade climática separando as áreas de Cerrado e Caatinga (maior sazonalidade na precipitação, temperaturas mais altas) das áreas do domínio Atlântico, de clima mais ameno e maiores altitudes. Assim, os fragmentos amostrados apresentam características de metacomunidades, com grande dissimilaridade florística e estrutural condicionada principalmente por fatores climáticos e pela influência da vegetação dos domínios fitogeográficos adjacentes.

Palavras-chave: Estrutura; Florística; Florestas decíduas; Domínios fitogeográficos; Metacomunidades.

\section{INTRODUCTION}

Seasonal Dry Tropical Forests (SDTFs) are phyto-ecological units characterized by specific climatic and edaphic attributes, such as seasonality, annual mean rainfall less than $1800 \mathrm{~mm}$, a dry season lasting for 3 to 6 months lower than $100 \mathrm{~mm}$ of precipitation and high fertility soils (Prado \& Gibbs, 1993; Pennington et al., 2000; Banda-R et al., 2016). They occur in disjoint nuclei distributed around the Neotropical region, from Northern Argentina and Northeastern Brazil to Northwest Mexico (Pennington et al., 2000; Santos et al., 2012; Mogni et al., 2015; Castellanos-Castro \& Newton, 2015).

SDTFs compose a gradient of vegetation size and deciduousness associated with climatic seasonality and soil fertility, varying from shrubby physiognomies in xeric sites with lower fertility to large forests in more humid and fertile sites (Pennington et al., 2009). High fertility and facility of handling soil became SDTFs historically attractable for agricultural practices, resulting in high forest degradation (Nunes et al., 2013; Sunderland et al., 2015; Banda-R et al., 2016). SDTFs biogeographic patterns observed by Prado \& Gibbs (1993) gave rise to Pleistocene Arc Theory, suggesting that vegetation nuclei would be relics of a continuous seasonal formation during the last Quaternary glaciation some 21 thousand years ago, when climatic and atmospheric conditions would be favorable to its expansion (Pennington et al., 2000; Mogni et al., 2015).

The pleistocene xeric arc would have become disjointed with the beginning of the present interglacial period, when humid formations and savannas resurfaced (Ab'Saber, 1977; Prado \& Gibbs, 1993; Pennington et al., 2000; Mogni et al., 2015). Although considered in some studies, current studies reject the existence of a wide interconnected dry formation, since predictive models of vegetation suggest that there was no significant expansion of neotropical biomes during the last Pleistocene glaciation (Mayle et al., 2004; Werneck et al., 2011; Vieira et al., 2015; Linares-Palomino et al., 2015; Caetano et al., 2008). As a result of their environmental and evolutionary characteristics, SDTF core areas would have remained stable and only the transitional areas would have responded to climate fluctuations (Werneck et al., 2011, Pennington \& Lavin, 2016).

Beyond SDTF nuclei, several patches may have been conserved in other domains, always in association with carbonaceous outcrop rocks, poorly developed or incipient soils, rich in macronutrients, with moderate $\mathrm{pH}$ and low levels of aluminum (Ribeiro \& Walter, 2008; Rossatto et al., 2015). These formations present their own characteristics, mainly due to the combination between limestone substrate, incipient soil and climatic and floristic influences of the adjacent domains (Ribeiro \& Walter, 2008; Rossatto et al., 2015). Although included in large scale studies with SDTFS (Prado \& Gibbs, 1993; Santos et al., 2012; Banda-R et al., 2016), these disjunctions under limestone are still poorly understood in spite of their peculiarity and importance for understanding the biogeographic patterns of tropical vegetation. Thus, little is known about the diversity patterns in these areas (Apgaua et al., 2014; Rossatto et al., 2015), as well as how edaphic, climatic and ecological attributes influence their characteristics (Arruda et al., 2015; Castellanos-Castro \& Newton, 2015; Neves et al., 2015).

Therefore this study aims to compare the phytogeographic, structural and physiognomic relationships between SDTFs on limestone outcrops in three (3) phytogeographic domains in Brazil. We proposed the following hypotheses: (i) The communities floristic composition on 
outcrops is strongly influenced by the phytogeographic domain of their occurrence; (ii) The environmental variables (precipitation, seasonality, longitude, altitude and temperature) reflect the phytogeographic domains, and therefore also influence the composition of sampled communities; and (iii) Outcrops rocks have a similar structure due to nutritional conditions related to the limestone presence.

\section{MATERIAL AND METHODS}

\section{Study site}

We sampled eight SDTF patches on outcrops of carbonate rock (Figure 1). Outcrops are distributed in Cerrado (3 patches), Atlantic ( 2 patches) and Caatinga (3 patches) domains, all located in Brazilian karst region or semi-arid, humid and sub-humid depressions from the lower Paleozoic (Ab'Saber, 2003), as can be seen in Table 1. Surroundings outcrops are deciduous forests inserted in an anthropic matrix, composed by pasture and monocultures. All patches were in good condition but with evidence of anthropogenic interference. Patches from Matozinhos, Nova Roma and Santo Hipólito core vegetation and surroundings presented signs of selective cutting.

\section{Data collection}

The shrub-tree horizontal structure characterization in each patch was performed by quadrant sampling. A transect of $435 \mathrm{~m}$ was established from an arbitrary point; from there another 29 subsequent points were sampled every $15 \mathrm{~m}$, following the direction of the largest axis of the fragment (Durigan, 2003; Freitas \& Magalhães, 2012). Stems with a breast height diameter (DBH) greater than or equal to $3.7 \mathrm{~cm}$ were identified, numbered and measured. To complement the list of sampled species in the phytosociological survey, a floristic survey was carried out by walking in all the fragments, obeying the sampling inclusion criteria and identified according to APG IV (Angiosperm Phylogeny Group, 2016). This survey was carried out on both the outcrop rocks and its surroundings vegetation.

On other hand, we selected three (3) climatic variables, namely: (i) annual mean precipitation, (ii) mean temperature of months and (iii) average dry season (seasonality) from WordClim 1.4 database for characterization of this region (Hijmans et al., 2005). Geographical variables such as Longitude and altitude were collected along the sampling areas using GPS.

Table 1. Climatic and geographical characteristics of sampled patches

\begin{tabular}{cccccccc}
\hline Patch & Dom & Latitude & Longitude & Alt & Köppen & Prec & Temp \\
\hline Matozinhos & Atl & $19^{\circ} 33^{\prime} 08.9^{\prime \prime} \mathrm{S}$ & $44^{\circ} 04^{\prime} 14.4^{\prime \prime} \mathrm{W}$ & 788 & Cwa & 1338 & 21,5 \\
Doresópolis & Atl & $20^{\circ} 18^{\prime} 25.2^{\prime \prime} \mathrm{S}$ & $45^{\circ} 55^{\prime} 08.5^{\prime \prime} \mathrm{W}$ & 821 & Cwa & 1421 & 21,1 \\
Santo Hipólito & Cer & $18^{\circ} 17^{\prime} 23.7^{\prime \prime} \mathrm{S}$ & $4^{\circ} 11^{\prime} 13.9^{\prime \prime} \mathrm{W}$ & 621 & Aw & 1096 & 22,8 \\
Vila Propício & Cer & $1^{\circ} 29^{\prime} 14.0^{\prime \prime} \mathrm{S}$ & $48^{\circ} 51^{\prime} 52.7^{\prime \prime} \mathrm{W}$ & 674 & Aw & 1477 & 24,9 \\
Nova Roma & Cer & $13^{\circ} 42^{\prime} 25.7^{\prime \prime} \mathrm{S}$ & $46^{\circ} 51^{\prime} 14.5^{\prime \prime} \mathrm{W}$ & 687 & Aw & 1110 & 24,0 \\
Bom Jesus da Lapa & Caat & $1^{\circ} 03^{\prime} 13.9^{\prime \prime} \mathrm{S}$ & $43^{\circ} 17^{\prime} 28.6^{\prime \prime} \mathrm{W}$ & 466 & As & 846 & 25,3 \\
Januária & Caat & $1^{\circ} 08^{\prime} 03.1^{\prime \prime} \mathrm{S}$ & $44^{\circ} 14^{\prime} 58.4^{\prime \prime} \mathrm{W}$ & 643 & Aw & 987 & 23,4 \\
Monte Rei & Caat & $14^{\circ} 28^{\prime} 03.7^{\prime \prime} \mathrm{S}$ & $44^{\circ} 10^{\prime} 37.9^{\prime \prime} \mathrm{W}$ & 502 & Aw & 987 & 23,4 \\
\hline
\end{tabular}

Dom: Phytogeographical Domain; Atl: Atlantic; Cer: Cerrado; Caat: Caatinga; Alt: Altitude (m); Köppen: Climate type according to Köppen Classification (Alvares et al., 2013). Prec: Annual precipitation ( $\mathrm{mm} /$ year); Temp: Mean temperature of months $\left({ }^{\circ} \mathrm{C}\right)$; Cwa: seasonal with cold winter and hot summers; Aw: tropical savannah. As: hot and humid tropical, with dry summer and autumn-winter rains. 


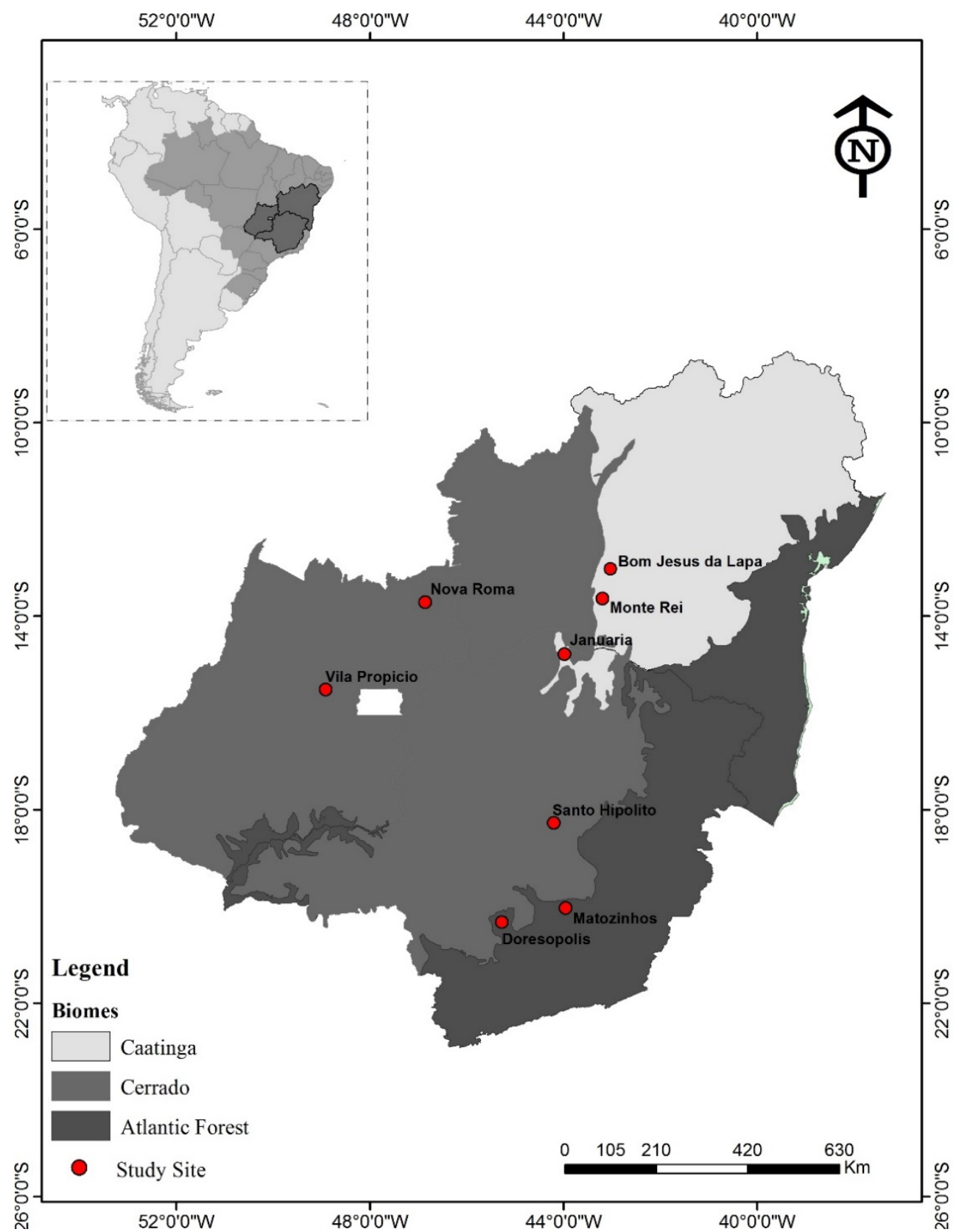

Figure 1. Geographic distribution of sampled patches on limestone outcrops in different Brazilian phytogeographic domains

\section{Data analysis}

In order to make comparisons and verify existing patterns in communities' structure, phytosociological parameters were calculated: D- Density; RD - relative density; Do Dominance; RD - relative dominance and CV - coverage value (Mueller-Dombois \& Ellember, 1974). The Shannon-Winner diversity index $\left(H^{\prime}\right)$ was used to calculate Alpha diversity and Pielou (') to determine evenness (Magurran, 1988) for each studied patch. In order to test if there is variation between phytosociological parameters, ANOVA and Tukey test at 5\% significance were done (Zar, 1996). The similarity between formations was obtained through the Jaccard index, in order to evaluate if the floristic composition is different at $5 \%$ significance between formations on different domains (Krebs, 1989; Anderson \& Walsh, 2013). A Dendrogram was performed using paired group algorithms and Jaccard similarity index in 
order to observe if the outcrops are more similar to each other forming a cohesive floristic unit, or if they are more similar with the environment matrix (surrounding vegetation) where they are inserted (Krebs, 1989). For its validation we used the Cophenetic Correlation Coefficient (CCC), which is based on the correlation between the distance matrix elements and corresponding coefficients to form groups (Charrad et al., 2014; Brock et al., 2008).

In order to test possible correlations between the variations of species composition on geo-climatic variables in outcrops rocks, the Canonic Correspondence Analysis (CCA) (Ter Braak, 1995) was used. The Monte Carlo permutation test was used to reveal the effect of the environmental variables on the species composition. Thus, two matrices were elaborated: (i) a binary (biotic) matrix containing the sampled species from floristic and phytosociological surveys on outcrops rocks, when species present were represented by the number "1" and when absent by " 0 "; (ii) an abiotic secondary matrix containing localities and geo-climatic variables. Floristic links between CCAs were represented through Venn diagrams, plotting common and exclusive species in the groups. The analyses were performed in the R Core Team (2016) program, in the "vegan" (Oksanen et al., 2017) and "betapart" (Baselga, 2013) packages.

\section{RESULTS}

We found 263 species distributed in 47 families and 156 genera, with 126 species sampled $(48 \%)$ in the floristic survey. Four (4) families most represented in species richness were Fabaceae (64 species), Myrtaceae (23), Euphorbiaceae (13) and Malvaceae (12), which together represented $42 \%$ of the sampled taxa.

Average density was lower in Nova Roma, at about 14.74 ind.ha $^{-1}$ and higher in Doresópolis at about 83.91 ind.ha ${ }^{-1}$. On other hand, Santo Hipólito presented a higher dominance, at about $150.61 \mathrm{~m}^{2}$.ha-1, while in Doresópolis it was lower, at about 19.46 (Table 2). Species richness and diversity indexes did not show a clear distinction between domains. The dominant species were differentiated along the domains, and the communities presented specific structure characteristics of their occurrence site.

Table 2. Density (D), Dominance (Do), Species richness (S), Shannon diversity index (H') and Pielouevenness index (J') for the sampledpatches

\begin{tabular}{|c|c|c|c|c|c|c|}
\hline Domain & Patches & D (ind.ha-1) & Do $\left(m^{2} \cdot h a^{-1}\right)$ & $S$ & $\mathbf{H}^{\prime}$ & $J^{\prime}$ \\
\hline Atlantic & Doresópolis & $83.91 \pm 15.40^{a}$ & $19.46 \pm 9.20^{d}$ & 25 & 2.42 & 0.75 \\
\hline Caatinga & Monte Rei & $64.72 \pm 14.06^{b}$ & $114.14 \pm 37.67^{b}$ & 30 & 2.63 & 0.77 \\
\hline Caatinga & Bom Jesus & $64.18 \pm 19.26^{b}$ & $100.31 \pm 38.01^{b}$ & 16 & 2.04 & 0.74 \\
\hline Atlantic & Matozinhos & $52.56 \pm 12.66^{\mathrm{bc}}$ & $88.15 \pm 17.67^{b}$ & 37 & 3.1 & 0.86 \\
\hline Cerrado & Santo Hipólito & $50.22 \pm 14.56^{\mathrm{bc}}$ & $150.61 \pm 14.23^{a}$ & 28 & 2.6 & 0.78 \\
\hline Caatinga & Januária & $44.29 \pm 10.48^{b c}$ & $108.55 \pm 11.08^{b}$ & 53 & 3.73 & 0.94 \\
\hline Cerrado & Vila Propício & $30.48 \pm 12.49^{c d}$ & $111.83 \pm 20.29^{b}$ & 35 & 3.14 & 0.88 \\
\hline Cerrado & Nova Roma & $14.74 \pm 12.18^{\mathrm{cd}}$ & $74.78 \pm 15.90^{\mathrm{bc}}$ & 33 & 3.04 & 0.87 \\
\hline
\end{tabular}

Letters a, b, c and d represent the Tukey test at 5\% significance. Values +/- represent standard deviations

Species of wide occurrence in domains presented phytosociological representativeness in at least one outcrop rock, being among the 10 species of higher coverage value (CV). Of these species, Ceiba pubiflora (A.St.-Hil.) K. Schum, CV around 8.3, occurred in five (5) outcrop rocks; Myracrodruon urundeuva Allemão, CV around 16.3 in four and Aspidosperma pyrifolium Mart. \& Zucc., CV around 7.7 in three (3). Three species occurred among the ten (10) largest CV in two outcrops: Cereus jamacaru DC, CV around 8.8, (Vila Propício and Nova Roma); Machaerium scleroxylon Tul., CV around 13.5, (Doresopolis and Nova Roma) and Aralia 
warmingiana (Marchal) J. Wen, CV around 5.8, (Santo Hipólito and Monte Rei); and two (2) species occurred among the ten largest CV in only one outcrop rock: Machaerium dimorphandrum Hoehne, CV around 6.2 (Matozinhos) and Acacia polyphylla (DC.) Britton \& Rose, CV around 4.5, (Nova Roma).

Three domains presented high specificity compositions in the outcrop rocks and surrounding areas, which culminated in low floristic similarity between phytogeographic domains. This result is demonstrated by the low Jaccard similarity values between areas, even within the same domain and low species sharing exposed in the Venn diagrams (Figure 2). A total of 104 (about 39\%) species occurred only in surrounding vegetation; 11 species (around $4 \%$ ) occurred between the outcrop rocks and surrounding vegetation, but did not occur simultaneously in both environments in the same outcrop; and 123 species (around 47\%) occurred in both environments. There is a low occurrence of common species among the three phytogeographical domains, mainly those that occurs on the outcrops. The Atlantic domain presented the lowest number of shared species, while the fragments Cerrado and Caatinga domains remained closer, with a considerable number of common species (Figure 2).

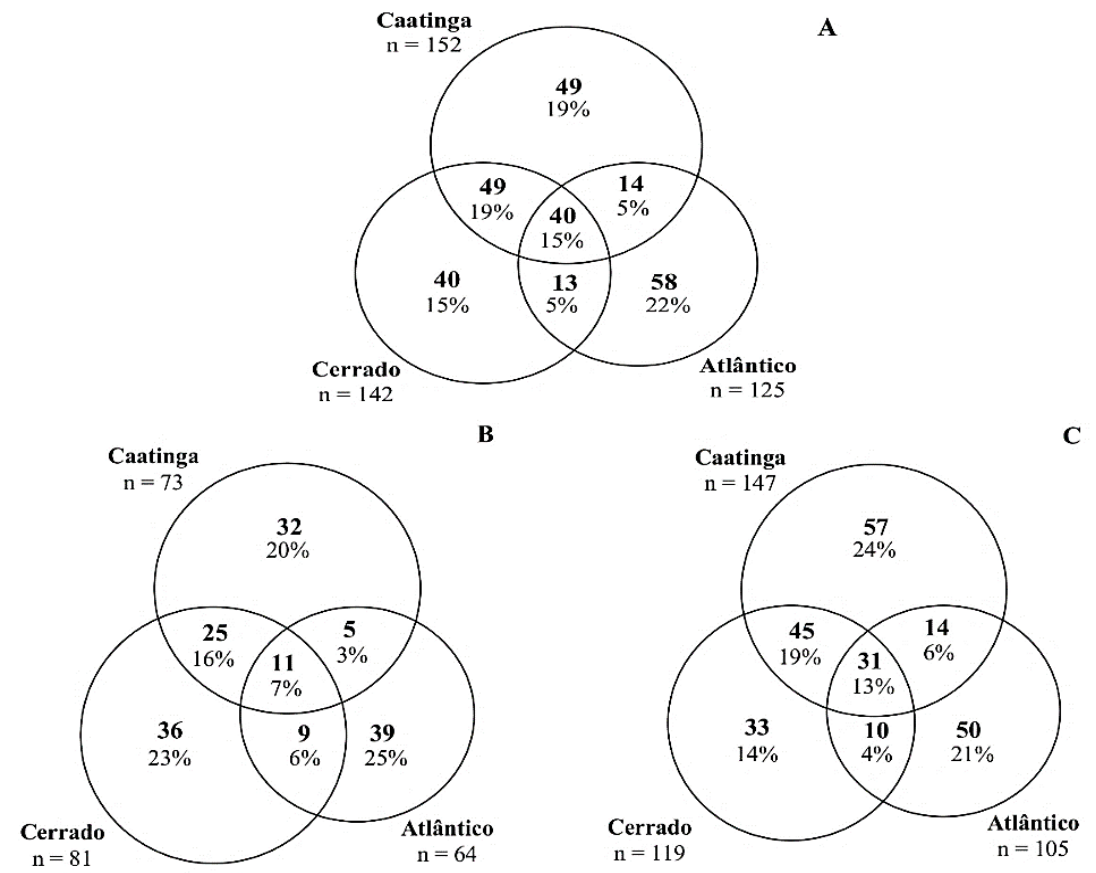

Figure 2. Shared species among eight (8) fragments of seasonally dry tropical forests (SDTF), grouped by phytogeography domain to which they belong. A - Flora on outcrops and surrounding vegetation; B flora on the outcrops rock and C - flora on the surrounding vegetation.

Low floristic similarity between the outcrops rock was confirmed by dendrogram analysis (Figure 3). In general, outcrops are more similar to their surroundings and make patterns that match domains where they are inserted. However, outcrops in Vila Propício and Nova Roma were floristically closer to each other than to the surroundings, with Bom Jesus da Lapa also being distinguished by its dissimilarity with the surroundings vegetation. In Doresópolis the outcrop area still appears as a subset of its surroundings; in Matozinhos as well.

Environmental variables significantly influenced the species composition in different domains, with a pattern of beta diversity associated mainly to seasonality, precipitation and longitude. Outcrops were grouped according to the domain to which they belong (Figure 4). Only the Outcrop in Vila Propício remained distant from the other Cerrado fragments, while Santo Hipólito was poorly related with environmental variables. The main gradient is defined by climatic seasonality, separating outcrops with lower annual rainfall and longer dry seasons (Caatinga - Bom Jesus da Lapa, Monte Rei and Januária, Cerrado - Nova Roma, Vila Proprício and Santo Hipólito), to outcrops under the Atlantic domain influence (Doresópolis and 
Matozinhos), with higher altitudes, higher precipitation and milder temperatures. The secondary gradient (second ordering axis) separated the Caatinga and Cerrado outcrops; in this case, annual mean precipitation and longitude were the main responsible variables. A long gradient of species distribution was observed through the high eigenvalues found for the first two ordering axes of the Canonical Correspondence Analysis (CCA - Axis $1=0.69$ and Axis $2=0.55$ ) (Figure 4). In this way, it is possible to infer that there is a strong substitution of species between outcrops (Ter Braak, 1995). The Monte Carlo permutation test was significant for the first canonical axis separately (F-ratio $=0.569, \mathrm{P}=0.022$ ) and for the set formed by all the axes (F-ratio $=1.403, \mathrm{P}=0.016$ ), which allows to infer that the correlation between the species distribution and the environmental variables was significant.

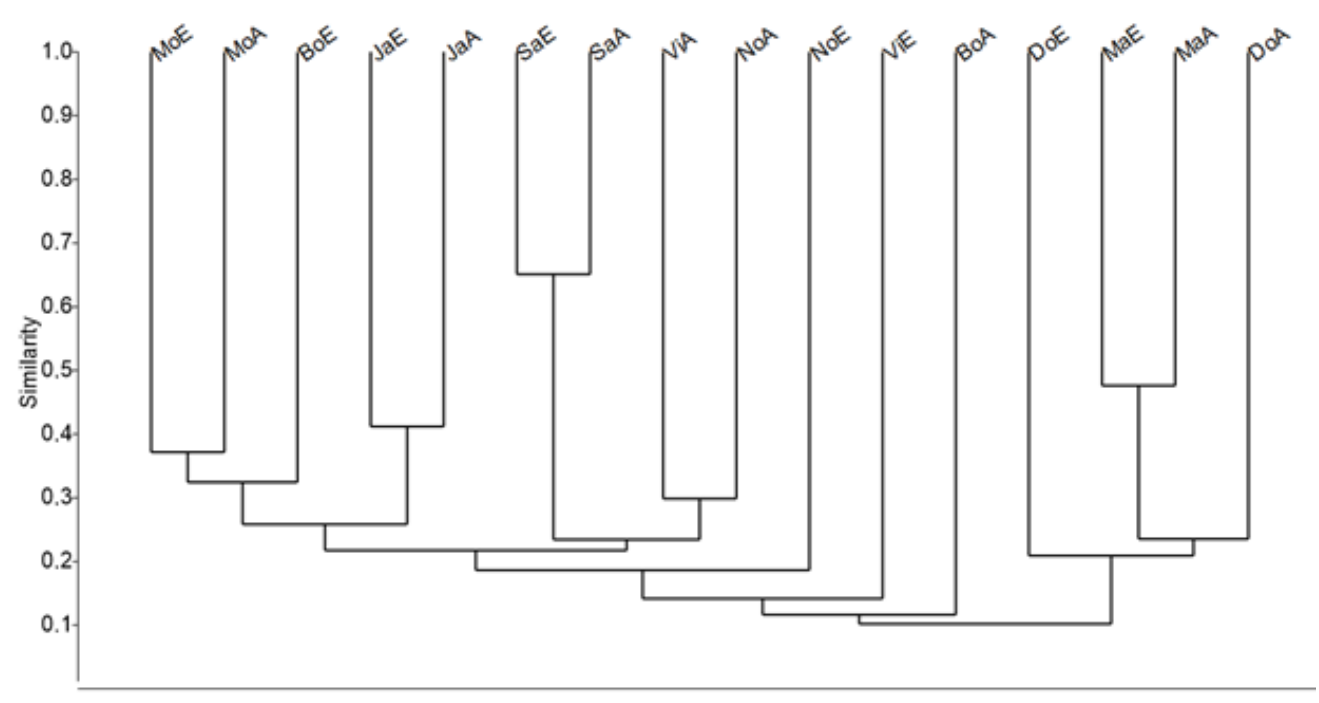

Figure 3. Dendrogram using Jaccard similarity index showing similarities between the outcrop flora and the surrounding vegetation (Terminal letters in the dendrogram indicate "A": Outcrop; "E": Surrounding). Where: Mo- Monte Rei; Bo- Bom Jesus da Lapa; Ja- Januária; Sa- Santo Hipólito; Vi- Vila Propício; MaMatozinhos; No- Nova Roma; Do- Doresópolis. Cophenetic Correlation Coefficient (CCC $)=0.86$

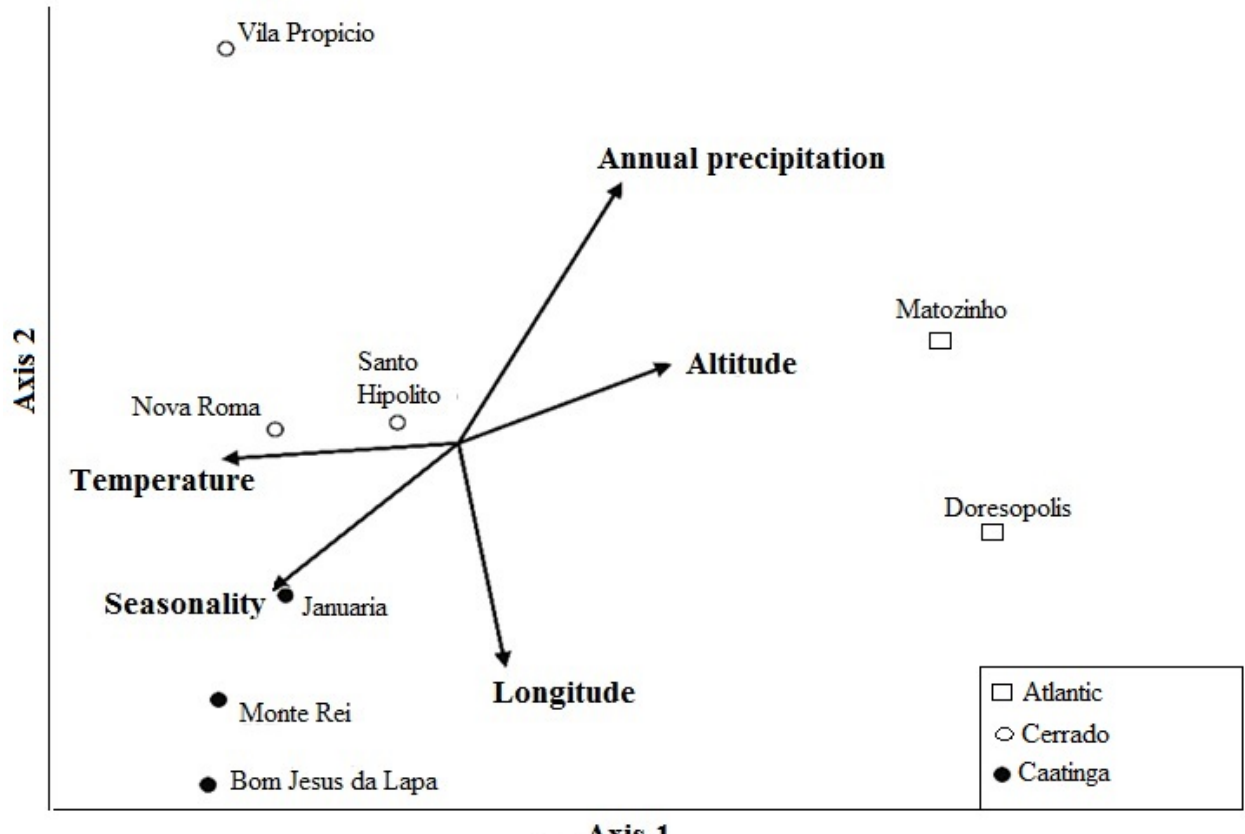

Axis 1

Figure 4. Canonical correspondence analysis for the eight (8) fragments on Atlantic, Cerrado and Caatinga Domains. 


\section{DISCUSSION}

The SDTF fragments studied did not present a similar structure conditioned by limestone outcropping as expected, so we reject the third hypothesis. However, the species of large occurrence shared among the fragments presented the highest coverage values, which may indicate a certain connection between them. Beyond structural differentiation, there was great floristic dissimilarity between domains, with climatic seasonality separating sampled areas in the Caatinga and Cerrado domains to those present in the Atlantic domain. Thus, annual mean precipitation and longitude was the main determinant factors of differentiation between Caatinga and Cerrado, corroborating the other two hypotheses, respectively. This was observed by previous studies (Oliveira-Filho \& Fontes, 2000; Neves et al., 2017) where climatic variables associated to continentality (ocean distance) seem to play a preponderant role in SDTF physiognomy differentiation.

The absence of structural similarity between fragments within the same domain (Matozinhos and Doresopolis from the Atlantic domain for example) may be related to the depth of the soil, which is quite variable in these sites (Rossatto et al., 2015), or with the successional stage and anthropic disturbances to which they are subject. More advanced forests have a high basal area, high diversity and low species dominance (Moreira et al., 2013), as observed for the fragment in Januária and may be indicative of good conservation status of these areas (Nunes et al., 2003). In addition to Januária; Vila Propício, Matozinhos and Nova Roma presented a similar structure, with high diversity and evenness when compared to other SDTFs (Santos et al., 2011; Nunes et al., 2013; Menino et al., 2015).

The species of wide distribution common among the fragments presented high coverage value, enabling us to indicate a connection between these fragments. Among them, $\mathrm{S}$. polyphylla, A. pyrifolium, C. publiflora, C. jamacaru and M. urundeuva are reported as characteristic of SDTFs (Fiaschi \& Pirani, 2009; Santos et al., 2012). The last occurs in fertile soils and presents an intrinsic relationship with elements like $\mathrm{Ca}, \mathrm{Mg}, \mathrm{N}$ and $\mathrm{P}$ present on limestone outcrop (Rossatto et al., 2015). Persistence of these species may be associated with the conservation of functional characteristics commonly attributed to SDTF species (Pennington et al., 2009). The conservation of these characteristics throughout the evolutionary process resulted in a greater aptitude of these species to the environment, as it makes them more competitive in relation to the other species and boosts their chances of permanence in these habitats (Caetano et al., 2008; Pennington et al., 2009). The proximity between Vila Propício and Nova Roma fragments (closer to each other than to the surroundings vegetation) and the floristic distance between some fragments and their surroundings (greater in Bom Jesus da Lapa and smaller in Doresópolis) may indicate a past connection between these fragments, but suppressed by the long influence of the surroundings flora on these places. For the studied fragments, the domains in which they are inserted is preponderant in the floristic composition (Vieira et al., 2015; LinaresPalomino et al., 2015; Pennington \& Lavin, 2016).

SDTFs' environments on limestone outcrop are associated with eutrophic soils with severe seasonality, factors that have selected the species with an ability to withstand drought and defoliation (Rossatto et al., 2015). They are complex formations, both structurally and floristically, with their internal variations reflect the evolutionary processes and the edaphoclimatic variables (Pennington et al., 2009; Neves et al., 2015; Banda-R et al., 2016; Castellanos-Castro \& Newton, 2015). We found high species substitution among fragments, which corroborate other studies to explain the high beta diversity commonly found in SDTFS areas, generally higher than other tropical formations. (Pennington et al., 2009; Santos et al., 2012; Apgaua et al., 2015; Menino et al., 2015; Banda-R et al., 2016). In fact, there was a low floristic similarity between fragments on the same domain (except for Vila Proprício and Nova Roma), showing the influence of the surrounding vegetation on the fragment composition. At low scales, colonization by surroundings species can be facilitated by edaphic factors (Siefert et al., 2012); in the case of SDTF on limestone outcrops mainly by soil depth, which 
determines water retention (Rossatto et al., 2015) and may represent a filter for species establishment (Menino et al., 2015; Banda-R et al., 2016).

Long-term precipitation seasonality and temperature influence the evolution and speciation of arboreal taxa and condition the vegetation distribution (Oliveira-Filho \& Fontes, 2000). Floristic differentiation between the fragments was due to climatic seasonality, separating fragments present in the domains by higher temperature, seasonality and lower precipitation (Cerrado and Caatinga) to humid areas, higher altitude and lower temperatures (Atlantic). For differentiation between the Cerrado and Caatinga fragments, annual mean precipitation and longitude were preponderant factors. Siefert et al. (2012) postulate that the climatic variables aforementioned control the composition of large-scale species. Thus, besides the climate being predominant for the determination of vegetation in the domains, geographical distance contributes to differentiation of flora fragments, since the closer, the greater is the similarity between them (Oliveira-Filho et al., 2006; Rodal et al., 2008). SDTFs fragments present in the Cerrado domain exemplify this geographic role on floristic dissimilarity, since they are the most distant among them, and the least cohesive group of the three. Santo Hipólito outcrops, which have a central geographical position in relation to other outcrops, also occupied a central position in the ordering diagram, with floristic similarity intermediate to the three outcrops groups.

The absence of a defined structural pattern and high species substitution among the fragments on limestone outcrop are an important point about the conservation of these areas. High beta diversity had already been reported for SDTF (Pennington et al., 2009; Santos et al., 2012; Apgaua et al., 2014, 2015; Banda-R et al., 2016) but it is worth mentioning that this metacommunity structure was found in the present study in formations that occur on the same substrate type. Even minimizing the substrate effect on differentiation of SDTFs areas, they continue to present peculiarities that distinguish them, mainly by the differentiated species range, with particular structure to each fragment. Due to the poor conservation state of remaining SDTFs fragments, large numbers of species of economic interest and pressure for the agricultural use of these areas (Pennington et al., 2009; Nunes et al., 2013; CastellanosCastro \& Newton, 2015; Banda-R et al., 2016), the need for conservation is urgent for the ecological and evolutionary processes' maintenance, intrinsic to these environments.

\section{CONCLUSION}

The SDTFs fragments on limestone outcrops sampled in this study show little floristic and structural similarity, except for Nova Roma and Vila Propício fragments, conditioned mainly by climatic factors and the vegetation influence of the phytogeographic domains into which they are inserted. On the other hand, climatic seasonality was the key floristic dissimilarity factor, separating Caatinga and Cerrado domains from Atlantic. Annual mean precipitation and longitude was the determinant factors for differentiation between Caatinga and Cerrado as well.

\section{ACKNOWLEDGMENTS}

We thank the Coordination for the Improvement of Higher Education Personnel (CAPES) and Foundation for Minas Gerais Research Support (FAPEMIG) for financial support and scholarship grants to the authors.

\section{REFERENCES}

Ab'Saber, A. N. (1977). Espaços ocupados pela expansão dos climas secos na América do Sul, por ocasião dos períodos g/aciais quaternários. Universidade de São Paulo/Instituto de Geografia.

Ab'Saber, A. N. (2003). Os domínios de natureza no Brasil: potencialidades paisagísticas (160 p). São Paulo: Ateliê. 
Alvares, C. A., Stape, J. L., Sentelhas, P. C., Gonçalves, J. L. M., \& Sparovek, G. (2013). Koppen's climate classification map for Brazil. Meteorologische Zeitschrift, 22(6), 711-728. http://dx.doi.org/10.1127/0941-2948/2013/0507.

Anderson, M. J., \& Walsh, D. C. I. (2013). PERMANOVA, ANOSIM, and the Mantel test in the face of heterogeneous dispersions: what null hypothesis are you testing? Ecological Monographs, 83(4), $557-$ 574. http://dx.doi.org/10.1890/12-2010.1.

Angiosperm Phylogeny Group - APG. (2016). An update of the Angiosperm Phylogeny Group classification for the orders and families of flowering plants: APG IV. Botanical Journal of the Linnean Society, 181(1), 1-20. http://dx.doi.org/10.1111/boj.12385.

Apgaua, D. M. G., Pereira, D. G. S., Santos, R. M., Menino, G. C. O., Pires, G. G., Fontes, M. A. L., \& Tng, D. Y. P. (2015). Floristic variation within seasonally dry tropical forests of the Caatinga Biogeographic Domain, Brazil, and its conservation implications. International Forestry Review, 17(2), 33-44. http://dx.doi.org/10.1505/146554815815834840.

Apgaua, D. M. G., Santos, R. M., Pereira, D. G. S., Menino, G. C. O., Pires, G. G., Fontes, M. A. L., \& Tng, D. Y. P. (2014). Beta-diversity in seasonally dry tropical forests (SDTF) in the Caatinga Biogeographic Domain, Brazil, and its implications for conservation. Biodiversity and Conservation, 23(1), 217-232. http://dx.doi.org/10.1007/s10531-013-0599-9.

Arruda, D. M., Schaefer, C. E., Corrêa, G. R., Rodrigues, P. M., Duque-Brasil, R., Ferreira-Jr, W. G., \& Oliveira-Filho, A. T. (2015). Landforms and soil attributes determine the vegetation structure in the Brazilian semiarid. Folia Geobotanica, 50(3), 175-184. http://dx.doi.org/10.1007/s12224-015-9221-0.

Banda-R, K., Delgado-Salinas, A., Dexter, K. G., Linares-Palomino, R., Oliveira-Filho, A., Prado, D., Pullan, M., Quintana, C., Riina, R., Rodríguez M, G. M., Weintritt, J., Acevedo-Rodríguez, P., Adarve, J., Álvarez, E., Aranguren B, A., Arteaga, J. C., Aymard, G., Castaño, A., Ceballos-Mago, N., Cogollo, Á., Cuadros, H., Delgado, F., Devia, W., Dueñas, H., Fajardo, L., Fernández, Á., Fernández, M. Á., Franklin, J., Freid, E. H., Galetti, L. A., Gonto, R., González-M, R., Graveson, R., Helmer, E. H., Idárraga, Á., López, R., Marcano-Vega, H., Martínez, O. G., Maturo, H. M., McDonald, M., McLaren, K., Melo, O., Mijares, F., Mogni, V., Molina, D., Moreno, N. D., Nassar, J. M., Neves, D. M., Oakley, L. J., Oatham, M., OlveraLuna, A. R., Pezzini, F. F., Dominguez, O. J., Ríos, M. E., Rivera, O., Rodríguez, N., Rojas, A., Särkinen, T., Sánchez, R., Smith, M., Vargas, C., Villanueva, B., \& Pennington, R. T. (2016). Plant diversity patterns in neotropical dry forests and their conservation implications. Science, 353(6306), 13831387. PMid:27708031.

Baselga, A. (2013). Betapart-package: partitioning beta diversity into turnover and nestedness components. $R$ package version 1.3. Vienna: R Foundation for Statistical Computing. Retrieved in 2017, April 19, from https://CRAN.R-project.org/package=betapart

Brock, G., Vasyl, P., Susmita, D., \& Somnath, D. (2008). CIValid: an R package for cluster validation. Journal of Statistical Software, 25(4), 1-22. http://dx.doi.org/10.18637/jss.v025.i04.

Caetano, S., Prado, D., Pennington, R. T., Beck, S., Oliveira-Filho, A., Spichiger, R., \& Naciri, Y. (2008). The history of Seasonally dry tropical forests in eastern South America: Inferences from the genetic structure of the tree Astroniumurundeuva (Anacardiaceae). Molecular Ecology, 17(13), 3147-3159. PMid:18522691. http://dx.doi.org/10.1111/j.1365-294X.2008.03817.x.

Castellanos-Castro, C., \& Newton, A. C. (2015). Environmental heterogeneity influences successional trajectories in Colombian seasonally dry tropical forests. Biotropica, 47(6), 660-671. http://dx.doi.org/10.1111/btp.12245.

Charrad, M., Ghazzali, N., Boiteau, V., \& Niknafs, A. (2014). NbClust: an R package for determining the relevant number of clusters in a data set. Journal of Statistical Software, 61(6), 1-36. http://dx.doi.org/10.18637/jss.v061.i06.

Durigan, G. (2003). Métodos para análise de vegetação arbórea. In L. Cullen Junior, R. Rudran \& C. Valladares-Pádua (Eds.), Métodos de estudos em biologia da conservação e manejo da vida silvestre. Curitiba: UFPR, Fundação Boticário de Proteção à Natureza.

Fiaschi, P., \& Pirani, J. R. (2009). Review of plant biogeographic studies in Brazil. Journal of Systematics and Evolution, 47(5), 477-496. http://dx.doi.org/10.1111/j.1759-6831.2009.00046.x.

Freitas, W. K., \& Magalhães, L. M. S. (2012). Métodos e parâmetros para estudo da vegetação com ênfase no estrato arbóreo. Floresta e Ambiente, 19(4), 520-540. http://dx.doi.org/10.4322/floram.2012.054.

Hijmans, R. J., Cameron, S. E., Parra, J. L., Jones, P. G., \& Jarvis, A. (2005). Very high resolution interpolated climate surfaces for global land areas. International Journal of Climatology, 25(15), $1965-$ 1978. http://dx.doi.org/10.1002/joc.1276. 
Krebs, C. J. (1989). Ecological methodology. New York: Harper and Row.

Linares-Palomino, R., Aybar, D., \& Morales Ruiz, E. J. (2015). Floristics of neotropical seasonally dry forests: a perspective from complete vascular plant inventories. Phytocoenologia, 45(3), 251-267. http://dx.doi.org/10.1127/phyto/2015/0010.

Magurran, A. E. (1988). Ecological diversity and its measurement. Princeton: Princeton University Press. http://dx.doi.org/10.1007/978-94-015-7358-0.

Mayle, F. E., Beerling, D. J., Gosling, W. D., \& Bush, M. B. (2004). Responses of Amazonian ecosystems to climatic and atmospheric carbon dioxide changes since the last glacial maximum. Philosophical Transactions of the Royal Society of London. Series B, Biological Sciences, 359(1443), 499-514. PMid:15212099. http://dx.doi.org/10.1098/rstb.2003.1434.

Menino, G. C. D. O., Santos, R. M. D., Apgaua, D. M. G., Pires, G. G., Pereira, D. G. S., Fontes, M. A. L., \& Almeida, H. D. S. (2015). Florística e estrutura de florestas tropicais sazonalmente secas. Cerne, 21(2), 277-291. http://dx.doi.org/10.1590/01047760201521021609.

Mogni, V. Y., Oakley, L. J., \& Prado, D. E. (2015). The distribution of woody legumes in neotropical dry forests: the Pleistocene Arc Theory 20 years on. Edinburgh Journal of Botany, 72(1), 35-60. http://dx.doi.org/10.1017/S0960428614000298.

Moreira, B., Fonseca, S. N., \& Carvalho, F. A. (2013). Regeneração natural e relações ecológicas com o estrato arbóreo em um fragmento urbano de floresta atlântica. Revista de Biologia Neotropical, 10(1), 21-27. http://dx.doi.org/10.5216/rbn.v1i1.25454.

Mueller-Dombois, D., \& Ellember, G. H. (1974). Aims and methods of vegetation ecology. New York: John Wiley \& Sons.

Neves, D. M., Dexter, K. G., Pennington, R. T., Bueno, M. L., \& Oliveira Filho, A. T. (2015). Environmental and historical controls of floristic composition across the South American Dry Diagonal. Journal of Biogeography, 42(8), 1566-1576. http://dx.doi.org/10.1111/jbi.12529.

Neves, D. M., Dexter, K. G., Pennington, R. T., Valente, A. S. M., Bueno, M. L., Eisenlohr, P. V., Fontes, M. A. L., Miranda, P. L. S., Moreira, S. N., Rezende, V. L., Saiter, F. Z., \& Oliveira-Filho, A. T. (2017). Dissecting a biodiversity hotspot: The importance of environmentally marginal habitats in the Atlantic Forest Domain of South America. Diversity \& Distributions, 23(8), 898-909. http://dx.doi.org/10.1111/ddi.12581.

Nunes, Y. R. F., Luz, G. R., Souza, S. R., Silva, D. L., Veloso, M. D. M., Espírito-Santo, M. M., \& Santos, R. M. (2013). Floristic, structural, and functional group variations in tree assemblages in a Brazilian Tropical Dry Forest: effects of successional stage and soil properties. In A. Sánchez-Azofeifa, J. S. Powers, G. W. Fernandes \& M. Quesada (Eds.), Tropical dry forests in the Americas: ecology, conservation, and management. New York: CRC Press. http://dx.doi.org/10.1201/b15417-19.

Nunes, Y. R. F., Mendonça, A. V. R., Botezelli, L., Machado, E. L. M., \& Oliveira-Filho, A. D. (2003). Variações da fisionomia, diversidade e composição de guildas da comunidade arbórea em um fragmento de floresta semidecidual em Lavras, MG. Acta Botanica Brasílica, 17(2), 213-229. http://dx.doi.org/10.1590/S0102-33062003000200005.

Oksanen, J., Blanchet, F. J., Friendly, M., Kindt, R., Legendre, P., McGlinn, D., Minchin, P. R., O'Hara, R. B., Simpson, G. L., Solymos, P., Stevens, M. H. H., Szoecs, E., \& Wagner, H. (2017). Vegan: community ecology package. R package version 2.4-2. Retrieved in 2017, April 19, from https://cran.rproject.org/package=vegan

Oliveira-Filho, A. T., \& Fontes, M. A. (2000). Patterns of floristic differentiation among Atlantic Forests in southeastern Brazil and the influence of climate. Biotropica, 32(4b), 793-810. http://dx.doi.org/10.1111/j.1744-7429.2000.tb00619.x.

Oliveira-Filho, A. T., Jarenkow, J. A., \& Rodal, M. J. A. (2006). Floristic relationships of seasonally dry forests of eastern South America based on tree species distribution patterns. In R. T. Pennington, J. A. Ratter \& G. P. Lewis (Eds.), Neotropical savannas and dry forests: plant diversity, biogeography and conservation. New York: CRC Press. http://dx.doi.org/10.1201/9781420004496-7

Pennington, R. T., \& Lavin, M. (2016). The contrasting nature of woody plant species in different neotropical forest biomes reflects differences in ecological stability. The New Phytologist, 210(1), $25-$ 37. PMid:26558891. http://dx.doi.org/10.1111/nph.13724.

Pennington, R. T., Lavin, M., \& Oliveira-Filho, A. (2009). Woody plant diversity, evolution, and ecology in the tropics: perspectives from seasonally dry tropical forests. Annual Review of Ecology Evolution and Systematics, 40(1), 437-457 . http://dx.doi.org/10.1146/annurev.ecolsys.110308.120327. 
Pennington, R. T., Prado, D. E., \& Pendry, C. A. (2000). Neotropical seasonally dry forests and Quaternary vegetation changes. Journal of Biogeography, 27(2), 261-273. http://dx.doi.org/10.1046/j.13652699.2000.00397.x.

Prado, D. E., \& Gibbs, P. E. (1993). Patterns of species distributions in the dry seasonal forest of South America. Annals of the Missouri Botanical Garden, 80(4), 902-927. http://dx.doi.org/10.2307/2399937.

R Core Team. (2016). R: a language and environment for statistical computing. Vienna: R Foundation for Statistical Computing. Retrieved in 2017, April 19, from https://www.R-project.org/

Ribeiro, J. F., \& Walter, B. M. T. (2008). As principais fitofisionomias do Bioma Cerrado. In S. M. Sano, S. P. Almeida \& J. F. Ribeiro (Eds.), Cerrado: ecologia e flora (pp. 151-213). Brasília: Embrapa Cerrados/Embrapa Informação Tecnológica.

Rodal, M. J. N., Barbosa, M. R. V., \& Thomas, W. W. (2008). Do the seasonal forests in northeastern Brazil represent a single floristic unit? Brazilian Journal of Biology = Revista Brasileira de Biologia, 68(3), 467475. http://dx.doi.org/10.1590/S1519-69842008000300003.

Rossatto, D. R., Carvalho, F. A., \& Haridasan, M. (2015). Soil and leaf nutrient content of tree species support deciduous forests on limestone outcrops as a eutrophic ecosystem. Acta Botanica Brasílica 29(2), 231-238. http://dx.doi.org/10.1590/0102-33062014abb0039.

Santos, R. M., Barbosa, A. C. M. C., Almeida, H. S., Vieira, F. A., Santos, P. F., Carvalho, D. A., \& OliveiraFilho, A. T. (2011). Caatinga arbórea em Juvenília, norte de Minas Gerais, Brasil. Cerne, 17(2), 247258. http://dx.doi.org/10.1590/S0104-77602011000200013.

Santos, R. M., Oliveira-Filho, A. T., Eisenlohr, P. V., Queiroz, L. P., Cardoso, D. B. O. S., \& Rodal, M. J. N (2012). Identity and relationships of the Arboreal Caatinga among other floristic units of seasonally dry tropical forests (SDTFs) of North-eastern and Central Brazil. Ecology and Evolution, 2(2), 409-428. PMid:22423333. http://dx.doi.org/10.1002/ece3.91.

Siefert, A., Ravenscroft, C., Althoff, D., Alvarez-Yépiz, J. C., Carter, B. E., Glennon, K. L., Heberling, J. M., Jo, I. S., Pontes, A., Sauer, A., Willis, A., \& Fridley, J. D. (2012). Scale dependence of vegetationenvironment relationships: a meta-analysis of multivariate data. Journal of Vegetation Science, 23(5), 942-951. http://dx.doi.org/10.1111/j.1654-1103.2012.01401.x.

Sunderland, T., Apgaua, D., Baldauf, C., Blackie, R., Colfer, C., Cunningham, A. B., Dexter, K., Djoudi, H., Gautier, D., Gumbo, D., Ickowitz, A., Kassa, H., Parthasarathy, N., Pennington, R. T., Paumgarten, F., Pulla, S., Sola, P., Tng, D., Waeber, P., \& Wilmé, L. (2015). Global dry forests: a prologue. International Forestry Review, 17(2), 1-9. http://dx.doi.org/10.1505/146554815815834813.

Ter Braak, C. J. F. (1995). Ordination. In R. H. G. Jongman, C. J. F. Ter Braak \& O. F. R. Van-Tongeren (Eds.), Data analysis in community and landscape ecology (pp. 91-274). Cambridge: Cambridge University Press. http://dx.doi.org/10.1017/CBO9780511525575.007.

Vieira, F. A., Novaes, R. M. L., Fajardo, C. G., Santos, R. M., Almeida, H. S., Carvalho, D., \& Lovato, M. B. (2015). Holocene southward expansion in seasonally dry tropical forests in South America: phylogeography of Ficusbonijesulapensis (Moraceae). Botanical Journal of the Linnean Society, 177(2), 189-201. http://dx.doi.org/10.1111/boj.12241.

Werneck, F. P., Costa, G. C., Colli, G. R., Prado, D. E., \& Sites Junior, J. W. (2011). Revisiting the historical distribution of Seasonally Dry Tropical Forests: new insights based on palaeodistribution modelling and palynological evidencegeb. Global Ecology and Biogeography, 20(2), 272-288. http://dx.doi.org/10.1111/j.1466-8238.2010.00596.x.

Zar, J. H. (1996). Biostatistical analysis. Englewood Cliffs: Prentice-Hall.

Authors' contributions: NCAF and AJRP: conceptualization, investigation, formal analysis, validation, visualization methodology, writing; CRS: formal analysis, validation; PFS and HSA: visualization, methodology; FAV: data curation, formal analysis, methodology; ATO, EVDB and DC: conceptualization, investigation; supervision; RMS: conceptualization, investigation, formal analysis, funding acquisition, project administration. 